\title{
Erratum to: Abdominal Fascial Flaps for Providing Total Implant Coverage in One-Stage Breast Reconstruction: An Autologous Solution
}

Tonguc Isken · Murat Onyedi · Hakki Izmirli •

Sahin Alagoz $\cdot$ Ryan Katz

Published online: 20 October 2009

(C) Springer Science+Business Media, LLC and International Society of Aesthetic Plastic Surgery 2009

Erratum to: Aesth Plast Surg

DOI 10.1007/s00266-009-9384-2

The name of one of the authors of this article (Ryan Katz) was inadvertently omitted in the online and print versions published previously. His name is presented correctly here.

The online version of the original article can be found under doi:10.1007/s00266-009-9384-2.

T. Isken $(\bowtie) \cdot$ M. Onyedi · H. Izmirli · S. Alagoz

Department of Plastic and Reconstructive Surgery, Kocaeli

University Faculty of Medicine, Kocaeli, Turkey

e-mail: tongucisken@yahoo.com

R. Katz

Department of Plastic and Reconstructive Surgery,

Johns Hopkins University School of Medicine,

Baltimore, MD, USA 